\title{
ULAMA, JAWARA, DAN UMARO: Studi Tentang Elite Lokal di Banten
}

\author{
Karomani \\ Universitas Lampung \\ Email: aom_karomani@ yahoo.co.id
}

\begin{abstract}
ABSTRAK. Elite adalah kelompok orang yang memegang peran penting dalam masyarakat. Ulama, jawara, dan umaro di Banten merupakan elite lokal yang memiliki pengaruh dalam masyarakat. Ulama memiliki pengaruh kuat dalam bidang keagamaan, jawara memiliki pengaruh kuat dalam bidang adat, seni dan budaya, dan umaro memiliki pengaruh kuat dalam jaringan kekuasaan pemerintahan. Dalam perjalanan sejarah elite acapakli terjadi perubahan dominasi elite. Ulama dan umaro dahulu memegang peran penting dan dominan dalam struktur stratifikasi sosial masyarakat Banten dibandingkan dengan elte jawara. Bahkan pendiri kesultanan Banten Syarif Hidayatullah dan anaknya Sultan Hasanudin adalah seorang ulama. Dewasa ini dominasi elite di Banten cenderung bergeser. Ulama bukan lagi elite dominan. Dalam era otonomi daerah, jawara di Banten tampak menjadi elite yang amat berkuasa. Jawara memperoleh lahan bermain di lingkungan pemerintahan yang amat menguntungkan posisi politik dan ekonominya dibandingkan dengan elite ulama.
\end{abstract}

Kata Kunci: elite lokal, ulama, jawara, umaro.

\section{ULAMA, JAWARA, AND UMARO: A Study of Local Elites in Banten}

\begin{abstract}
Elites are group which have important roles in society. Ulama, jawara, and umaro in Banten are local elites who have influence in the society. The ulama has a strong influence in the field of relegion, the jawara has a strong influence in the field of culture and traditional customs and the umaro has a strong influence in the network power of governance. Sometime change of elites domination happen in elite history. Formerly, ulama and umaro had more influence in social stratification than jawara elite. Furtheremore, the founder of Banten Sultanate Syarif Hidayatullah and his son Sultan Hasanudin were ulamas. Nowaday, elite domination have been replaced. Ulama is no longer an elite dominant anymore. In autonomy era, jawara has dominant power than ulama. Jawara gets acces in bureaucracy. Teherefore, jawara's politic and economy position more advantageous than ulama.
\end{abstract}

Key words: local elite, ulama, jawara, umaro. 


\section{PENDAHULUAN}

Sebagaimana dikemukakan Nashir (2000:21) istilah elite digunakan pada abad ke-17 untuk menyebut barang-barang dagangan yang mempunyai keutamaan khusus yang kemudian digunakan juga untuk menyebut kelompokkelompok sosial yang tinggi seperti kesatuan-kesatuan militer atau kalangan bangsawan atas. Sigkatnya, menurut Nashir elite adalah orang-orang yang sangat berbakat atau orang terbaik dalam masyarakat. Lebih jauh Nashir (2000:21) menjelaskan bahwa dalam sosiologi istilah elite umumnya selalu dikaitkan dengan elite politik. Pandangan ini menurutnya didasarkan atas asumsi ihwal teori tentang elite yang membagi atau membedakan anggota masyarakat antara elite dan massa sebagai sesuatu yang tidak terhindarkan dalam kehidupan moderen yang kompleks. Elite adalah kelompok aktor yang memiliki kekuasaan. Elite sebagai orang atau sekelompok orang yang memegang posisi terkemuka dalam suatu masyarakat (Nashir, 2000:22). Para elite diakui Wijaya (1982: 63-64) bukan hanya memposisikan dirinya di atas anggota masyarakat, tetapi sekaligus berusaha mempertahankan statusnya melalui sub-elite yang terdiri atas kelompok besar dari kelas menengah baru, aparatur pemerintah, manajer, administratur, ilmuwan atau kaum intelektual yang menyediakan kader baru bagi kader elite di atasnya.

Kartodirdjo (1983: viii) mensinyalir seiring proses modernisasi sejak zaman kolonial terutama pada awal abad 20 di Indonesia telah terjadi sirkulasi elite atau perputaran kedudukan dan peran elite dari elite tradisional ke elite birokrasi dan kaum intelegensia. Menjelaskan apa yang dikemukakan Kartodirdjo, Kuntowijoyo (1994: 117) mengemukakan, jika pada masa prakemerdekaan kaum priyayi dapat menduduki kedudukan dan peran sebagai abdi dalem dan ambtenar, kini muncul priyayi baru yaitu para pegawai negeri yang disebut sebagai elite birokrasi.

Studi tentang elite dalam ilmu sosial tentu saja termasuk bidang studi yang menarik karena melibatkan berbagai disiplin ilmu. Secara khusus studi sosiologi tentang elite sebagaimana dikemukakan Nashir (2000:18) menjadi bagian dari wilayah kajian sosiologi politik. Dalam sosiologi politik, teori tentang elite dikembangkan dalam kaitan perjuangan politik untuk meraih posisi utama dari persaingan kekuasaan. Studi tentang elite sebenarnya telah lama dilakukan orang. Kartodirdjo yang menyunting beberapa tulisan tentang elite menyimpulkan bahwa studi tentang elite dalam karya-karya kelasik banyak menitikberatkan pada pengaruh atau peranan yang besar dari kekuasaan kelompok elite. Karya-karya lain menurut Kartodirdjo (1983:ix) banyak mengungkapkan studi tentang elite dalam kaitan kesejahteraan dan lingkungan kebudayaan tertentu yang menentukan jalannya perkembangan masyarakat. Emerson sebagaimana dianalisis Alfian (1978: 275-276) secara khusus melakukan studi tentang elite di Indonesia dengan memusatkan perhatian pada pola-pola tingkah laku (konflik dan adaptasi) elite politik yang tetap bertahan dalam kehidupan politik di lingkungan 
birokrasi dan legislatif yang dikatakan sebagai studi tentang kebudayaan politik elite.

Dalam teori elite, mayoritas yang amorf didominasi oleh minoritas yang relatif kohesif. Ikhwal dominasi elite ini lebih jauh dikemukakan Martin (1993:279) yang menyatakan bahwa dominasi ini dicapai secara langsung dengan cara memonopoli cara-cara kekerasan atau secara tidak langsung melalui pengendalian "kalangan menengah" dengan otoritas tertentu dalam bidang yang terbatas, atau melalui kontrol "hegemoni" terhadap perumusan nilai-nilai sosial. Para anggota kalangan elite satu sama lain terikat oleh ikatan-ikatan keluarga, asal usul kelas, pendidikan, pengalaman, pekerjaan, dan kepentingan-kepentingan instisusional serta mengembangkan suatu kesadaran sejenis dan kepentingan-kepentingan bersama; sementara massa yang terpecah tidak mempunyai pengetahuan ataupun sumber-sumber untuk memperluas cakrawala pandangan mereka dan mewujudkan kepentingan umum mereka dalam menentang dominasi elite.

Para ahli teori mengenai elite menaruh perhatian besar terhadap latar belakang sosial dan atribut-atribut pribadi kalangan elite karena mereka berpendapat bahwa faktor-faktor tersebut pasti mempengaruhi distribusi kekuasaan. Alasan pentingnya latar belakang sosial elite diketahui dikemukakan Martin (1993:283) bahwa latar belakang sosial elite merupakan pedoman yang amat berguna untuk mengetahui ciri-ciri elite antara lain dalam hal: (1) kohesinya, (2) kepentingan pribadinya, (3) nilai-nilainya, (4) refresentatifitasnya terhadap kepentingan umum atau kalangan khusus yang ada kaitannya, (5) hasil kerjanya, dan kelancaran hubungannya dengan kelompok kepentingan lain.

Dalam perspektif Weberian menurut Ritzer (1992: 125) kajian tentang elite sebagai kajian sosiologi dapat diletakkan dalam kerangka pembahasan masalah tindakan sosial aktor dalam kaitan dengan aktor lain yang memiliki makna-makna subjektif. Struktur perilaku sosial atau tindakan sosial yang dikaji sosiologi dalam hubungannya dengan studi tentang elite dalam pandangan Nashir (2000: 18) terkait dengan struktur kepribadian, struktur sosial, dan struktur kebudayaan yang melingkupi kehidupan para elite tersebut.

Struktur perilaku sosial atau teori tindakan sosial menurut Weber (dalam Vegger, 1985: 171) menekankan pada keyakinan, kesadaran motivasi, dan tujuan pada diri anggota masyarakat yang semuanya memberi isi atau makna dan bentuk pada kelakuannya. Kelakuan individu dapat bersifat lahiriah atau batiniah yang berupa permenungan, perencanaan, dan pengambilan keputusan. Perilaku individu menjadi perilaku sosial atau tindakan sosial manakala individu itu memikirkan, mempertimbangkan, memperhitungkan kelakuan orang lain, dan mengarahkan kepada hal di luar dirinya itu. Manusia saling mengarahkan perilaku mitra interaksi di hadapannya. Jadi singkatnya, menurut Weber prikelakuan sosial selalu berakar dalam kesadaran individu dan bertolak dari situ. Weber (dalam Vegger,1985:174) selanjutnya mengklasifikasikan perilaku sosial manusia ke dalam empat tipe: 1) kelakuan yang diarahkan secara rasional kepada tercapainya suatu tujuan; 2) kelakuan yang berorientasi kepada suatu nilai seperti nilai 
keindahan, nilai keagamaan dan lain sebagainya; 3) kelakuan yang menerima otoritasnya dari perasaan atau emosi seseorang; dan 4) kelakuan yang didasari tradisi semata-mata. Keempat model perilaku ini tentu dalam kenyataannya tidak bisa dipisahkan secara tegas tetapi salah satunya akan mendominasi perilaku sosial individu itu sendiri.

Berkaitan dengan diskusi di atas, tulisan ini menelaah elite lokal Banten dari aspek sejarah munculnya elite, stratifikasi sosial dan dominasi elite Banten pada saat ini.

\section{LATAR HISTORIS MUNCULNTA ULAMA, JAWARA, DAN UMARO SEBAGAI ELITE LOKAL BANTEN}

Jawara, ulama, dan umaro di Menes Banten merupakan tokoh yang mempunyai pengaruh dan memegang peran penting bagi kehidupan masyarakat setempat. Ulama dan jawara di Banten telah menjadi simbol "kokolot" yang dituakan dalam memimpin masyarakat baik dalam acara ritual keagamaan maupun acara kemasyarakatan yang lain. Jawara dan ulama memiliki otoritas tertentu yang tidak dipunyai oleh para pemimpin formal (umaro), seperti kepala desa, dan camat. Meskipun demikian telah terjadi hubungan yang kuat dalam sistem pemerintahan dan kemasyarakatan antara ketiga elite tersebut. Tiga kekuatan yaitu ulama, jawara dan umaro menjadi suatu konfigurasi kepemimpinan yang satu sama lain saling menunjang. Ulama memiliki pengaruh kuat dalam bidang keagamaan, jawara memiliki pengaruh kuat dalam bidang adat, dan umaro memiliki pengaruh kuat dalam jaringan kekuasaan pemerintahan (Sunatra, 1997: 124)

Fenomena ulama atau kiai yang tampil sebagai elite lokal di Banten bisa dipahami manakala dilihat secara historis. Ulama sejak dahulu ketika jaman kejayaan Sultan Banten, telah menjadi salah satu elite dalam lingkungan kerajaan. Sistem sosial politik yang berpusat pada raja ini, semakin memperkuat otoritas kiai (ulama). Kiai waktu itu, bertindak tidak saja sebagai penerjemah nilai-nilai Islam dalam masyarakat, tetapi sekaligus tampil sebagai elite kerajaan. Dalam kaitannya dengan kekuasaan, pemimpin agama dan kerajaan adakalanya berpusat pada satu orang. Hal ini terjadi misalnya dengan pemerintahan kesultanan Banten pada masa lalu. Syarif Hidayatullah sebagai peletak kesultanan Banten dikenal sebagai seorang kiai; pilar utama penyebar agama Islam di Jawa Barat. Ia selain berfungsi sebagai seorang pemuka agama Islam, juga menjadi penguasa secara politis ( Hufad, 2004:204). Masuknya kalangan ulama ini pada elite kerajaan Banten, pada awalnya tidak terlepas dari peran Wali Songo yang diawali Sunan Ampel dan utamanya Sunan Gunung Jati (Syarif Hidayatullah) yang berhasil mengislamkan masyarakat Banten dan menjadikan Sultan Hasanudin putranya sebagai Raja Banten pertama (1552-1570) (Lubis, 2004:27). Secara historis, seiring dengan islamisasi yang dilakukan oleh institusi kerajaan inilah, peran ulama menjadi penting. Pada jaman keemasan Sultan Banten berikutnya yang dipimpin Sultan Ageng Tirtayasa (1651-1682) misalnya, orang-orang alim 
(ulama) dari luar negeri seperti Mekah, Turki, dan Mesir banyak berdatangan ke Banten guna menyemarakkan syiar Islam di wilayah tersebut. Bahkan Sultan Banten telah mengangkat Syekh Yusuf dari Makassar menjadi mufti kerajaan Banten dan sekaligus menjadi penasehat dalam urusan pemerintahan. Bersama ulama dan rakyat Banten kemudian Syekh Yusuf berperang melawan Belanda (Lubis, 2004:55).

Seiring makin menguatnya Islam di Banten, maka muncullah ulama-ulama Banten yang terkenal yang kemudian berperan penting dalam perjuangan melawan Belanda. Syekh Nawawi Albanteni (1813-1897) misalnya, seperti diakui Steenbrink (1984:117) merupakan ulama termashur di tingkat dunia sekalipun. Ulama kharismatik yang amat mencintai ilmu ini, telah mengarang ratusan kitab antara lain Tafsir Almunir yang diterbitkan di Timur Tengah yang sampai saat ini masih menjadi rujukan di pesantren-pesantren. 30 tahun bermukim di Tanah Suci, Syekh Nawawi telah mendapat penghargaan Fuqoha dan Hukama terakhir, Ulama'ul hijaz, Imamul Ulama-il Haramain. Syekh Nawawi menjadi guru besar di Mekah, dan telah menghasilkan ribuan anak didik di seluruh belahan dunia Islam. Murid-muridnya yang terkenal di Indonesia antara lain K.H. Halil (Madura), K.H. Hasyim As'ary (Jombang/pendiri NU), K.H. Tubagus Mohammad Asnawi (yang oleh sebagian orang Banten dianggap wali di Banten, Caringin Labuan), K.H. Raden Asnawi (Kudus) dan kiai-kiai kharismatik lain di seluruh Nusantara. Syekh Nawawi inilah sebagaimana dikatakan Lubis (2004: 99) kemudian memompa semangat muridnya untuk berjuang melawan penjajahan Belanda di tanah air. Runtuhnya kesultanan Banten pada abad ke-19 dan memudarnya agama dalam sistem kolonial tidak menyurutkan peran ulama dalam masyarakat Banten, malah loyalitas masyarakat justru beralih pada ulama yang berseberangan dengan pemerintahan bentukan penjajah. Selain otoritas keagamaan, para kiai inipun menjadi tokoh independen yang mampu menyaingi para birokrat bentukan pemerintah kolonial, sehingga pengaruhnya meluas tidak hanya di kalangan lapisan bawah, tetapi juga pada kaum bangsawan Banten. Runtuhnya kesultanan Banten tidak mengakhiri eksistensi ulama, karena ketika itu para ulama tidak semata-mata berada dalam wilayah kekuasaan (Kesultanan Banten) menjadi penasehat atau kadi, melainkan tidak sedikit ulama yang berada di luar sistem kekuasaan kerajaan seperti mereka yang memimpin pesantren-pesantren yang independensinya demikian kuat. Para ulama di Banten pada masa kesultanan Banten terbagi dua yakni (1) ulama penghulu yang berada di lingkungan keraton dan menjadi bagian dari elite priyai jawa; dan (2) ulama -pesantren yang berbasis di pesantren yang tersebar di pedalaman. Ulama corak ke dua ini lebih terkonsentrasi pada proses pembentukan umat yang berbasis di pondok-pondok pesantren dan tidak hilang seiring hilangnya kesultanan Banten (Hufad, 2004: 133).

Ulama di Banten termasuk di daerah Menes selain disegani karena otoritas keagamaannya, juga dikenal sebagai sosok guru, dan panutan yang mengayomi masyarakat. Dalam jaman pergerakan menentang penjajahan Belanda, ulama 
adalah pejuang di garis depan. Haji Wasid, Haji Abdul Karim, K.H.Tb Ismail, Haji Marzuki yang mengadakan pemberontakan di Cilegon (1888) terhadap kolonialisme Belanda menurut Kartodirdjo (1984;257-274), merupakan ulama kharismatik di Banten yang menakutkan Belanda, sehingga banyak melenturkan kebijakan Belanda dalam memperlakukan warga Banten, khususnya yang berkaitan dengan perasaan fanatisme keagamaannya. Bahkan sebagaimana dikemukakan Hamka (1982: 107) banyak diantara ulama besar Banten yang tertangkap Belanda dibuang ke berbagai daerah, dan malahan kemudian mereka membuat komunitas Islam di tempat pengasingannya. Haji Abdurrahman misalnya, dibuang ke Banda dan hingga kini kuburannya banyak diziarahi orang di Banda Naira. Haji Arsyad Tawil dibuang ke Gorontalo dan meskipun dibebaskan Belanda, akhirnya pulang kembali ke Gorontalo demi panggilan murid-muridnya yang amat mencintainya. Haji Haris dibuang ke Bukit Tinggi, dan di sana disegani dan dihormati oleh warga masyarakat. Almarhum di Bukit Tinggi disebut Engku Syekh Banten dan diabadikan namanya menjadi sebuah jalan di Kota Bukit Tinggi. Selain perjuangan ulama di Cilegon, TB. K.H.Achmad Chatib (menantu K.H.Asnawi Caringin) di Caringin Labuan Pandeglang, K.H.Abdul Hadi di Bangko Menes Pandeglang, K.H. Ali Yasin dan kiai-kiai lain telah mengadakan pemberontakan terhadap kolonilisme Belanda di Banten pada tahun 1926 (Williams, 2003:147). Demikian pula pada zaman revolusi, sosok ulama di Banten memegang peran yang amat penting. Kiai Achmad Chatib pada tanggal 2 September 1945 menjadi residen Banten pertama dari kalangan ulama. Selain itu, beserta ulama lain seperti K.H. Syam'un beliau berdua menjadi tokoh BKR (Badan Kemanan Rakyat) di Banten.

Seperti halnya ulama, jawara di Banten pada umunya secara historis memegang peran penting dalam kehidupan masyarakat. Pada awalnya jawara terkait dengan latar historis pada era kekuasaan sebelum ada pengaruh kekuasaan kesultanan Banten. Jawara muncul tatkala adanya basis pelatihan (kesatrian) para pasukan pengawal kerajaan Padjadjaran yang berada di bawah kekuasaan Pucuk Umun di Banten Lama. Para jawara merupakan perantara atau penghubung antara penguasa Padjadjaran dengan rakyatnya, yang bertugas mengawasi kelompok-kelompok masyarakat, memungut upeti, serta mengatur tugas lain untuk kepentingan kerajaan yang dilakukan kadang-kadang dengan kekerasan demi berjalannya roda pemerintahan tradisional. Setelah raja Padjadjaran dan Pucuk Umun menyerah pada Sultan Hasanudin, para jawara yang setia pada kerajaan itu menyerah dan beralih menjadi pengikut Sultan Hasanudin. Dalam perjalanannya kemudian, mereka bukan saja mahir dalam ilmu bela diri dan kekebalan, tetapi mereka mempelajari agama Islam dari para kiai sehingga aktualisasi kejawaraannya dilandasi oleh nilai-nilai dan norma agama (Adimihardja, 1991 dalam Hufad, 2004: 211 ).

Pada abad ke-19, ketika tekanan pemerintah kolonial terhadap masyarakat pribumi semakin besar, maka munculah perlawanan-perlawanan rakyat dan pusat perlawanan berada pada kiai dan pemimpin kesultanan. Para kiai umumnya 
memiliki dua kelompok santri yang berkembang sesuai dengan kemampuan mereka. Pertama adalah yang mempunyai kemampuan bakat di bidang ilmu agama, sehingga kelak akan menjadi kiai pula seperti gurunya, dan kedua adalah para santri yang mempunyai bakat yang berkaitan dengan bela diri. Sosok santri yang kedua inilah yang oleh kiai dibina dalam hal kekuatan fisik, dan kemudian menjadi jawara Banten yang biasa diklasifikasikan sebagai ulama jawara atau jawara ulama. Di sisi lain ada juga jawara di Banten yang semata-mata menggunakan elmu hideung, yakni ilmu kekebalan (kadugalan) yang tidak berdasarkan ajaran agama yang kemudian diklasifikasikan sebagai jawara (Lubis, 2004:127).

Pada saat kesultanan Banten dihapuskan Daendels pada abad ke-19, keadaan di Banten menjadi kacau dan seluruh tatanan sosial hampir ambruk. Dalam situasi seperti ini muncullah para pemimpin dari kalangan kiai dan elite perdesaan lainnya. Mereka secara radikal membangkitkan semangat perlawanan terhadap penguasa asing dan juga terhadap pamong praja. Dalam situasi seperti ini, perampokan, penyamunan, pembegalan terjadi di mana-mana. Malahan dalam perkembangannya kemudian sekitar tahun 1880 -an muncul perampok dan bandit tulen yang tidak ada kaitannya dengan perlawanan. Mereka merampok dan melakukan penggarongan tanpa pilih bulu (Kartodirdjo, 1984: 156-164). Mereka inilah yang membuat nama jawara menjadi cemar. Kemudian hal itu dimanfaatkan oleh pemerintah kolonial untuk meruntuhkan citra para pejuang yang sesungguhnya, dengan cara mencap atau memberi label bahwa semua kaum jawara Banten adalah bandit, sehingga perlawanan dalam bentuk gerakan sosial yang bermaksud melawan penjajah seperti perlawanan Ki Wasid (1888), dianggap sebagai onlusten (keonaran), ongeregeldheden (pemberontakan), complot (komplotan), woelingen (kekacauan), dan onrust (ketidakamanan) (Sunatra, 1997:180-181).

Sebagaimana dikatakan Tihami (1992:212) bahwa penguasa kolonial Belanda merasa repot dalam menghadapi kelompok jawara yang sering melakukan sabotase terhadap kepentingan Belanda. Melalui kolaborasi dengan kekuatan para santri yang dikomando kiai, para jawara menjadi salah satu kunci konsistensi, kontinuitas perjuangan masyarakat Banten dalam melawan kolonialisme bangsa kulit putih. Dalam pandangan positif seperti inilah, jawara sebagai individu dan kelompok merupakan simbol dan kebanggaan yang telah mengakar kuat dalam budaya lokal yang terinternalisasi dalam alam pikiran manusia Banten yang keberadaannya dirasakan menjadi pengayom rasa aman untuk masyarakat Banten. Itu sebabnya, dalam perjalanannya kemudian jawara bagi masyarakat Banten menjadi salah satu pilar kekuatan sosial politik dan kultural yang selalu diperhitungkan keberadaannya dalam masyarakat Banten.

Kepemimpinan kiai dan jawara berperan strategis di dalam sistem sosial dan sistem budaya. Kiai dengan ilmu agama yang dimilikinya menjadi rujukan utama masyarakat setempat dalam menyelesaikan berbagai masalah sosial di masyarakat. Jawara dengan kekuatan ekonomi dan fisiknya menjadikan wilayah 
Banten aman, karena umumnya pihak-pihak yang berniat merusak ketentraman warga akan berhadapan dengan jawara yang umumnya tergabung dalam perkumpulan persilatan. Kepemimpinan kiai dan jawara merupakan simbiosis mutualisme yang tidak terpisahkan dalam konstruk sosial dan budaya masyarakat Banten. Peran ini sebagaimana dikemukakan Dewi (2003: 243) amat jelas pada masa pra kemerdekaan yang dimainkan kedua elite ini sebagai pelopor perlawanan terhadap kolonialisme. Agama dan budaya telah merupakan sumber kekuasaan politik kepemimpinan kiai dan jawara. Sumber kekuasaan religius dan kultural (kiai dan jawara) jika dilihat dari kacamata kategorisasi kepemimpinan Max Weber, mereka memiliki corak kepemimpinan yang amat kuat (Johnson, 1986:229-231).

Selain ulama dan jawara, umaro di Banten termasuk tokoh yang memegang peran penting dalam kehidupan masyarakat. Munculnya elite birokrat (umaro) berkaitan dengan aspek latar pendidikan atau kaum terpelajar Banten. Kaum terpelajar ini identik dengan pemegang kekuasaan birokrasi di tingkat desa, kecamatan, kabupaten dan provinsi. Karena latar belakang pendidikannya inilah kaum terpelajar yang menjadi pamong praja menjadi elite lokal yang berpengaruh terhadap tata kehidupan masyarakat Banten. Mereka memiliki kekuasan formal dalam pemerintahan tetapi tidak bisa berdiri sendiri, melainkan tetap akan bergandengan dengan kiai dan jawara sebagai tokoh informal yang telah demikian mengakar kuat dalam budaya lokal tersebut.

Umaro di Banten adalah sosok birokrat. Birokrat adalah orang yang melakukan pekerjaan dalam sebuah birokrasi. Birokrat dengan birokrasinya sesungguhnya dimaksudkan sebagai sarana bagi pemerintah yang berkuasa untuk melaksanakan pelayanan publik sesuai dengan aspirasi masyarakat. Birokrasi adalah tipe dari suatu organisasi yang dimaksudkan untuk mencapai tugas-tugas administratif yang besar dengan cara mengkoordinasikan secara sistematis pekerjaan dari banyak orang. (Balu dan Meyer dalam Kumorotomo, 2002: 62 ). Birokrasi pada awalnya dibentuk supaya keputusan-keputusan pemerintah dapat dilaksanakan dengan sistematis melalui aparat-aparat negara. Keputusankeputusan politis hanya akan bermanfaat bagi setiap warga negara jika pemerintah mempunyai birokrasi yang tanggap, sistematis dan efesien. Max Weber sebagaimana dirangkum Donald P. Warwick (dalam Sunatra, 1997: 67) mengemukakan empat ciri utama birokrasi yakni: (1) adanya suatu struktur hirarkis yang melibatkan pendelegasian wewenang dari atas ke bawah dalam organisasai ; (2) adanya posisi atau jabatan-jabatan yang masing-masing memiliki tugas dan tanggung jawab yang tegas ;(3) adanya aturan-aturan, regulasiregulasi, dan standar-standar formal yang mengatur bekerjanya organisasi dan tingkah laku para anggotanya; (4) adanya personil yang secara teknis memenuhi syarat yang dipekerjakan atas dasar karir, dengan promosi yang didasarkan pada kualifikasi, dan penampilan 
Berbeda halnya dengan ulama dan jawara, pola kepemimpinan umaro atau birokrat di Banten apabila mengikuti teori Max Weber dapat digolongkan ke dalam jenis kepemimpinan rasional atau otoritas legal. Kepemimpinan jenis ini merupakan sebuah bentuk kepemimpinan yang terletak pada jabatan atau status yang dipegang oleh seseorang. Kekuasaan dalam kepemimpinan berdasarkan pada tata aturan legal (legal authority) (Weber dalam Rosyadi, 2004:145). Dalam kepemimpinan legal rasional, figur penguasa berkuasa dengan cara yang legal, dan pengikutnya hanya mengikuti aturan main yang telah menjadi ketetapan konstitusional. Itu sebabnya, pengikut atau bawahan tidak menunjukkan kepatuhan buta pada pemimpinnya.

\section{ULAMA, JAWARA, DAN UMARO DALAM STRUKTUR DAN STRATIFIKASI SOSIAL MASYARAKAT BANTEN}

Secara historis, struktur dan stratifikasi sosial orang Banten terkait dengan hakikat kebiasaan hidup lugas (egaliter). Pada masyarakat Banten selatan yang umumnya didiami suku Sunda misalnya, tidak ada undak usuk basa yang dipakai masyarakat seperti halnya masyarakat Sunda Priangan. Hakikat hidup seperti ini sebagaimana dikatakan Sumardjo (dalam Hufad, 2004:214) dipengaruhi oleh tradisi mata pencaharian berladang. Dalam tradisi masyarakat ladang (berhuma), nyaris tidak tampak dominasi kekuasaan antara satu dengan yang lainnya (mereka lebih otonom dalam menjalani kehidupannya), sehingga secara struktural masyarakat lebih bersifat horisontal, dan hampir tidak tampak adanya stratifikasi. Daerah Banten pernah berada dalam kekuasaan raja-raja yang berlatar belakang Hindu-Budha seperti Salakanagara, Purnawarman dan kerajaan Sunda. Pengaruh tradisi masyarakat Hindu yang biasanya mengenal penggolongan berdasarkan kasta sebagai dasar stratifikasi sosial masyarakat, tidak ditemukan dalam masyarakat Banten khususnya dan bahkan masyarakat Sunda pada umumnya. Hal ini dikemukakan Rosidi (dalam Hufad 2004:215) berikut:

.... tidak ada bukti yang mengindikasikan bahwa feodalisme di masyarakat Sunda pernah ada dan kuat mengakar; dan bahkan tidak terdapat bukti bahwa dalam masyarakat orang Sunda itu pernah dikenal keraton dan sejenisnya sebagai pusat kehidupan atau pusat kebudayaan raja-raja . "

Terkait dengan stratifikasi sosial di Banten, para ahli berpendapat bahwa stratifikasi sosial baru tampak menonjol kuat di Banten pada era kekuasaan Sultan Banten yang memperoleh pengaruh dari Sunda Cirebon dan Demak. Semenjak saat inilah stratifikasi sosial mulai mencolok di Banten. Namun berbeda dengan di Jawa Mojokuto yang oleh Geertz (1989:6-9) struktur sosial masyarakatnya diklasifikasikan ke dalam abangan, santri dan priyayi, masyarakat Banten struktur sosial masyarakatnya pada awalnya terutama pada masa kesultanan Banten terbagi dua yakni strata menak (bangsawan) dan rakyat 
biasa. Struktur sosial seperti ini kemudian berkembang menjadi tiga stratifikasi sosial yakni lapisan tinggi, lapisan menengah, dan lapisan bawah. Lapisan tinggi yaitu para sultan, menak-priyayi, dan pegawai tinggi istana pemerintahan beserta keluarga dan keturunannya. Lapisan menengah adalah orang-orang kaya pegawai menengah di lingkungan istana atau pegawai pemerintahan yang tidak termasuk dalam lapisan pertama. Lapisan ketiga adalah lapisan orang kebanyakan rakyat cacah biasa seperti pegawai rendah, kuli, petani, pedagang, dan nelayan. Berikut gambar stratifikasi sosial Masyarakat Banten selama abad 19 pasca pengaruh sultan Banten.

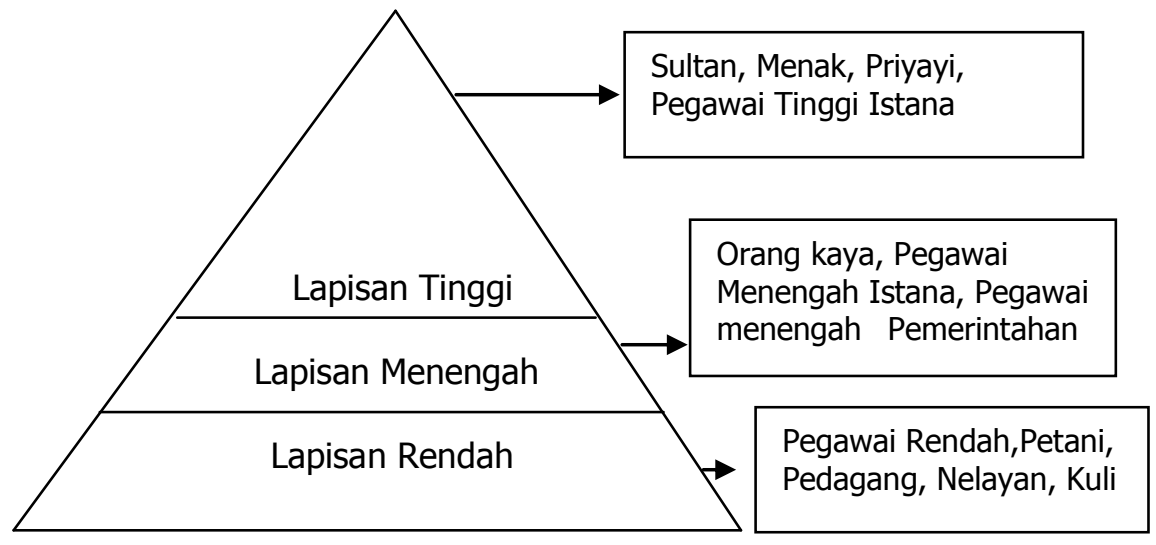

Gambar 1. Stratifikasi Masyarakat Menes abad 19 (Sumber Hufad, 2004:224)

Saat ini setelah berakhirnya kesultanan Banten, sebagaimana hasil penelitian yang dikemukakan Hufad (2004:222) dan Sunatra (1997:123-24), strata sosial yang terjadi pada abad ke-19 dalam masyarakat Banten itu telah berubah dan lebih ditentukan berdasar kekuatan: (1) birokrat (umaro); (2) ulama atau kiai; dan (3) Jawara. Ketiga kekuatan ini memiliki pengaruh dalam tata hubungan kekuasaan, baik di masyarakat maupun di pemerintahan.

Sesuai dengan stratifikasi sosial itu, jawara, ulama, dan umaro di Banten merupakan elite lokal yang mempunyai pengaruh dan memegang peran penting bagi kehidupan masyarakat. Ulama dan jawara di Banten telah menjadi simbol "kokolot" yang dituakan dalam memimpin masyarakat baik dalam acara ritual kegamaan maupun acara kemasyarakatan yang lain. Jawara dan ulama memiliki otoritas tertentu yang tidak dipunyai oleh para pemimpin formal (umaro), seperti kepala desa, camat dan lain-lain. Telah terjadi hubungan yang kuat dalam sistem pemerintahan dan kemasyarakatan antara ketiga elite tersebut. Tiga kekuatan: ulama, jawara dan umaro menjadi suatu konfigurasi kepemimpinan yang satu sama lain saling menunjang (Sunatra, 1977:124). Ulama memiliki pengaruh kuat dalam bidang keagamaan, jawara memiliki pengaruh kuat dalam bidang adat, 
dan umaro memiliki pengaruh kuat dalam jaringan pemerintahan. Startifikasi sosial ulama, jawara dan umaro di Banten dapat digambarkan sebagai berikut :

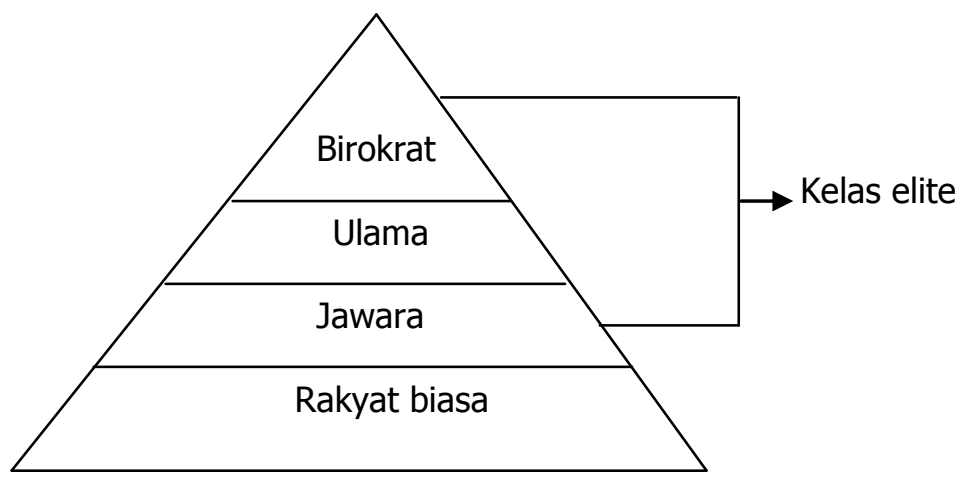

Gambar 2. Ulama, Jawara dan Umaro dalam Stratifikasi Sosial Masyarakat Banten (Sumber: Hufad, 2004:224)

\section{DOMINASI ELITE DI BANTEN}

Elite ulama, jawara dan umaro di Banten satu sama lain keberadaanya saling menunjang, namun acapkali di antara mereka kadang mengandung potensi konflik. Ulama misalnya yang lebih mendekatkan diri pada konsep kepemimpinan agama, dan jawara (yang bukan tipe jawara ulama) yang lebih memfokuskan pada kepemimpinan adat karuhun berbeda kepentingannya satu sama lain. Antara jawara dan ulama dilihat dari aspek ini ada konflik permanen. Jawara di satu sisi berkepentingan dengan adat atau tradisi karuhun yang dipengaruhi budaya Hindu, sementara ulama di sisi lain berkepentingan dengan proses islamisasi dan berusaha mengikis pengaruh Hindu tersebut (Sunatra, 1997:125). Demikian pula umaro acapkali dipandang elite lainnya mengandung potensi konflik karena misi atau pesan pembangunan yang disampaikannya kadang dipandang tidak sesuai dengan harapan masyarakatnya. Ulama yang mengikuti umaro tanpa terlebih dahulu dipahami maksud dan tujuannya, atau bertentangan maksud dan tujuannya dengan kehendak masyarakatnya akan dijauhi masyarakat, dan tidak lagi menjadi sosok panutan di lingkungannya.

Di lingkungan perdesaan Banten, ulama lebih banyak bertugas melayani penduduk dalam pelbagai peristiwa keagamaan, pembangunan (penyambung dengan pemerintah), bahkan berperan untuk merumuskan peraturan untuk suatu persoalan. Ulama ikut mewarnai keputusan di desa. Kedudukan seperti ini menempatkan ulama sebagai faktor integrasi, dan merupakan "interface"antara kepentingan masyarakat dan pemerintah. Namun demikian, sering terjadi hubungan ulama dan pemerintah (umaro) mengalami hubungan yang disharmoni. Masalah ini dikemukakan Rahardjo (1985:12) sebagai berikut: 
Kalangan luar sering amat tergesa-gesa penilaiannya terhadap pemimpin tidak resmi (kiai-pen) dari dunia pesantren ini. Lebih buruk lagi keadaannya, gagasan pembaharuan atau pembangunan itu selama ini diterjemahkan secara amat kasar oleh para pamong di tingkat daerah dan desa yang kemudian berakibat-jika mereka tidak berhasil bertemu pandang dengan pemimpin pesantren dan para kiaiterjadinya konflik antara pemimpin resmi dan pemimpin masyarakat, sedang kalau berhasil maka hal itu sering menciptidakan lekangnya pemimpin pesantren dengan anggota masyarakatnya.

Pandangan Raharjo itu masih terjadi pada saat ini di dunia pesantren yang ada di desa-desa di wilayah Banten. Ulama yang mengikuti apa kata pemerintah tanpa terlebih dahulu dipahami latar belakang atau motifnya oleh masyarakat acapkali dicap (dilabeli) sebagai ulama Su atau ulama dunia atau ulama materialistik.

Potensi konflik saat ini antarelite di Banten khususnya antara ulama dan jawara yang juga melibatkan umaro mudah dipahami manakala dilihat secara historis dan politik. Rezim orde baru sebagaimana dikemukakan Dewi (2003: 225) dahulu telah melakukan depolitisasi Islam di mana-mana. Dalam panggung orde baru, Islam sedapat mungkin dijauhkan dari politik, sehingga kekuatan dan pengaruh ideologisnya tidak menemukan dasar pijakannya yang kokoh. Rezim orde baru beserta jajaran birokratnya (umaro) yang merupakan koalisi Soeharto, ABRI dan teknokrat melihat Islam sebagai ancaman. Ini antara lain disebabkan sejarah Islam masa orde lama, utamanya pada masa demokrasi liberal yang memperlihatkan kerasnya perjuangan kelompok Islam yang diperankan Masyumi dan NU yang hendak memperjuangkan negara Islam dengan tokoh utama Mohamad Natsir. Keinginan ini terus berlanjut dalam masa orba. Dalam sidang MPR tahun 1986, kelompok Islam mendesak agar Piagam Jakarta diberlakukan. Bagi rezim orba ini merupakan ancaman serius bagi negara yang berdasarkan Pancasila. Karena itu, rezim orba beserta para birokratnya (umaro) menekan gerakan Islam yang memperjuangkan negara Islam. Atas dasar inilah posisi kiai sebagai entitas penting golongan Islam pada masa awal orba khususnya di Menes Banten, mengalami peminggiran dan pengucilan, sehingga tidak memiliki kekuasan dan pengaruh yang kuat dalam politik lokal di Banten. Sebaliknya, kepemimpinan kharismatik jawara dengan dukungan konstruk budaya Banten dipergunakan rezim orba beserta para birokratnya (umaro) melalui Golkar menjadi salah satu aset pengumpul dukungan politik di Banten. Jawara memperoleh keuntungan berupa akses politik, dan ekonomi sebagai landasan struktural bagi dominasinya di Banten.

Dominasi jawara tanpa ada kekuatan penyeimbang meningkatkan peluang memperbesar imperium kekuasaan dan memonopolinya. Studi Ben Anderson (1984 dalam Dewi, 2003: 226) atas kekuasaan Jawa memperlihatkan bahwa dalam budaya Jawa, kekuasaan merupakan benda konkrit yang jumlahnya 
terbatas dan tetap tidak berubah. Kekuasaan yang berada di luar miliknya mengakibatkan berkurangnya porsi kekuasaannya, maka segala bentuk kritik, oposisi harus ditekan habis. Pararel dengan konsep ini, maka kemungkinan besar kekuasaan yang dimiliki jawara di Banten, akan berusaha dipertahankannya dengan cara menekan pihak lain yang akan melemahkan kekuasaan dan legitimasi kepemimpinannya.

Dalam era otonomi daerah, jawara di Banten benar-benar menjadi elite yang dominan. Dalam pemilihan umum tahun 1999 PDIP memperoleh kursi 23 buah di DPRD Provinsi Banten, walaupun demikian dalam pemilihan Gubernur Banten pasangan Partai Golkar yang didukung jawara yang berkoalisi dengan PPP memenangkan kursi eksekutif sebagai wakil Gubernur dan Gubernur di Provinsi Banten. Demikian pula dalam pilihan kepala daerah (pilkada) provinsi Banten tahun 2006 Hj. Ratu Atut Khosiah putri ketua Pendekar Banten. H. Chasan Sochib yang diusung partai Golkar kembali menang menjadi gubernur Banten. Jawara telah berhasil mempergunakan dominasi dan pengaruh kepemimpinannya untuk meraih dukungan partai dan warga masyarakat dalam pemilihan Gubernur Banten dan ini memperkuat struktur politik elite jawara tersebut. Dengan demikian secara formal jawara memperoleh lahan bermain di lingkungan pemerintahan yang amat menguntungkan posisi politik dan ekonominya dibandingkan dengan elite lain khususnya, kiai (ulama). Jawara di Banten bahkan tidak hanya berkuasa di tataran eksekutif dan legislatif tetapi lembaga lain seperti KADIN Banten tidak terlepas dari dominasi kepemimpinannya.

Dapat dikatakan meskipun pada awalnya jawara diduga lahir dari ulama, pada perjalanannya kemudian dua elite ini bersimpang jalan karena kepentingan yang berbeda.. Realitas ini dikemukakan Nugraha (2006) berikut:

Pada perkembangan berikutnya, khususnya kiai dan jawara, menjadi kelompok terpisah dan seakan-akan berbeda mazhab. Pendulum zaman yang terus berputar selanjutnya mengubah citra jawara yang dulu sebagai patriot menjadi orang yang sekadar "menjual" otot. Tindak kriminal dan premanisme kerap dilekatkan. Bahkan dalam perpolitikan lokal saat maraknya pemilihan langsung kepala daerah, jawara dimobilisasi kandidat tertentu sebagai pengumpul suara.

Secara ringkas dapat disimpulkan bahwa di satu sisi secara teoretik sebagaimana dikatakan Sunatra (1977:124) ulama, jawara dan umaro di Banten menjadi suatu konfigurasi kepemimpinan yang saling menunjang, namun di sisi lain di antara mereka mengandung potensi konflik. Kemungkinan konflik ini antara lain disebabkan oleh kepentingan elite yang bersifat politik dan ekonomi. Jawara yang berkolaborasi dengan partai politik dan umaro di pemerintahan, secara politik dan ekonomi telah menggeser dominasi ulama di daerah ini. Ulama secara politik dan ekonomi nyaris tak memiliki akses kekuasaan seperti elite jawara dan umaro, meskipun disadari ulama tetap secara kultural memiliki pengaruh besar dalam masyarakat Banten. Hal ini berbeda dengan tahun 1947-an ketika para 
ulama di Banten hampir seluruhnya berada di lingkungan kekuasaan pemerintahan. Pada masa itu, Residen, bupati, camat sampai kepala desa dipegang dan sepenuhnya dibawah kendali para ulama (Lubis, 2004:178).

\section{SIMPULAN}

Ulama, jawara dan umaro di Banten merupakan elite lokal yang memiliki pengaruh besar dan peran penting dalam tatanan masyarakat. Ulama memiliki pengaruh kuat dalam bidang keagamaan, jawara memiliki pengaruh kuat dalam bidang adat, seni dan budaya, dan umaro memiliki pengaruh kuat dalam jaringan kekuasaan pemerintahan. Tiga kekuatan ini menjadi suatu konfigurasi kepemimpinan yang satu sama lain saling menunjang.

Dalam perjalanan sejarah elite ulama dan birokrat memegang peran penting dan dominan dalam struktur stratifikasi masyarakat Banten dibandingkan elite jawara. Bahkan pendiri kesultanan Banten Syarif Hidayatullah dan anaknya Sultan Hasanudin adalah seorang ulama. Demikian juga pada jaman keemasan Sultan Banten berikutnya yang dipimpin Sultan Ageng Tirtayasa (1651-1682) misalnya, sultan telah mengangkat Syekh Yusuf dari Makassar menjadi mufti kerajaan Banten dan sekaligus menjadi penasehat dalam urusan pemerintahan.

Dewasa ini dominasi elite di Banten telah bergeser. Ulama bukan lagi elite dominan. Dalam era otonomi daerah, jawara di Banten tampak menjadi elite yang amat berkuasa. Jawara memperoleh akses yang besar di lingkungan pemerintahan yang amat menguntungkan posisi politik dan ekonominya dibandingkan dengan elite ulama. Ulama secara politik dan ekonomi nyaris menjadi subordinasi daeri elite jawara dan umaro, meskipun disadari ulama tetap secara relegius memiliki pengaruh amat besar dalam masyarakat Banten.

\section{DAFTAR PUSTAKA}

Alfian. (1978). Pemikiran dan Perubahan Politik Indonesia. Jakarta: Gramedia.

Dewi, Kurniawati.H. (2003). Kepemimpinan Kiai dan Jawara di Banten Pengaruhnya terhadap Good Governance. Banten : LSPB.

Geert, Clifford. (1992). Tafsir Kebudayaan. Jakarta :Penerbit Kanisius.

Hamka. (1982). Dari Perbendaharaan Lama. Jakarta : Pustaka Panjimas.

Hufad, M.(2004). Sosialisasi Identitas Kekerabatan Pada Keluarga Inti di Menes Banten .Disertasi Doktor PPs Unpad Bandung.

Johnson, Doyle Paul. (1986). Teori Sosiologi Klasik dan Moderen I terj. Robert.MZ Lawang. Jakarta : Gramedia. 
Kartodirdjo, Sartono.(1984). Pemberontakan Petani Banten 1888. Jakarta: Pustaka Jaya.

Kartodirdjo, Sartono. (1983). Elite dalam Perspektif Sejarah. Jakarta: LP3S.

Kumorotomo, Wahyudi (2002). Etika Administrasi Negara. Jakarta: PT RajaGrafindo Persada.

Kuntowijoyo. (1994). Dinamika Sejarah Umat Islam Indonesia. Yogyakarta: Shalahudin Press.

Lubis, Nina. (2004). Banten dalam Pergumulan Sejarah. Jakarta: LP3S.

Martin, Roderick. (1993). Sosiologi Kekuasaan, terj.Herry Judiono. Jakarta: Rajawali Pers.

Nashir. (2000). Perilaku Politik Elite Muhammadiyah . Yogyakarta: PT. Tarawang.

Nugraha, Pepih. (2006). Jawara sebagai Kenyataan Sosial. http://www.kompas.com [09/09/06]

Rahardjo, M. Dawam. (1985). Pesantren dan Pembaharuan. Jakarta: LP3S.

Ritzer, Georg. (1992). Sociological Theory. Third Edition. New York: McGraw-Hill Inc.

Rosyadi, K. (2004). Mistik Politik Gus Dur. Yogyakarta: Penerbit Jendela Kacamata.

Sunantra. (1997). Integrasi dan Konflik Kedudukan Politik Jawara dan Ulama dalam Budaya Lokal. Studi Kasus Kepemimpinan di Banten. Bandung: PPs Unpad.

Steenbrink. A. Karel. (1984). Beberapa Aspek tentang Islam di Indonesia Abad ke19. Jakarta: Bulan Bintang.

Tihami. (1992). Kiai dan Jawara di Banten Studi tentang Agama, Magi, dan Kepemimpinan di Desa Pasanggrahan Serang. Jakarta. Universitas Indonesia.

Veegr.K.J. (1985). Realitas Sosial Refleksi Filsafat Sosial atas Hubungan IndividuMasyarakat dalam Cakrawala Sejarah Sosiologi. Jakarta: Gramedia.

Wijaya, Albert. (1982). Budaya Politik dan Pembangunan Ekonomi. Jakarta: LP3S.

Williams, Michael C. (2003). Arit dan Bulan Sabit. Pemberontakan Komunis 1926 di Banten. Terj. Chandra Utama. Jakarta: Syarikat Indonesia 